\title{
Applications of Antibody-Based Antigen Delivery Targeted to Dendritic Cells In Vivo
}

\author{
Jessica Bourque (i) and Daniel Hawiger * (D)
}

Citation: Bourque, J.; Hawiger, D. Applications of Antibody-Based Antigen Delivery Targeted to Dendritic Cells In Vivo. Antibodies 2022, 11, 8. https://doi.org/10.3390/ antib11010008

Academic Editor: Raphael Clynes

Received: 1 December 2021

Accepted: 20 January 2022

Published: 25 January 2022

Publisher's Note: MDPI stays neutral with regard to jurisdictional claims in published maps and institutional affiliations.

Copyright: () 2022 by the authors Licensee MDPI, Basel, Switzerland. This article is an open access article distributed under the terms and conditions of the Creative Commons Attribution (CC BY) license (https:// creativecommons.org/licenses/by/ $4.0 /)$.
Doisy Research Center, Department of Molecular Microbiology and Immunology, School of Medicine, Saint Louis University, 1100 S. Grand Blvd., St. Louis, MO 63104, USA; jess.bourque@health.slu.edu * Correspondence: daniel.hawiger@health.slu.edu; Tel.: +1-314-977-8875; Fax: +1-314-977-8717

\begin{abstract}
Recombinant immunoglobulins, derived from monoclonal antibodies recognizing the defined surface epitopes expressed on dendritic cells, have been employed for the past two decades to deliver antigens to dendritic cells in vivo, serving as critical tools for the investigation of the corresponding $\mathrm{T}$ cell responses. These approaches originated with the development of the recombinant chimeric antibody against a multilectin receptor, DEC-205, which is present on subsets of murine and human conventional dendritic cells. Following the widespread application of antigen targeting through DEC-205, similar approaches then utilized other epitopes as entry points for antigens delivered by specific antibodies to multiple types of dendritic cells. Overall, these antigen-delivery methodologies helped to reveal the mechanisms underlying tolerogenic and immunogenic $\mathrm{T}$ cell responses orchestrated by dendritic cells. Here, we discuss the relevant experimental strategies as well as their future perspectives, including their translational relevance.
\end{abstract}

Keywords: dendritic cells; antigen targeting; antigen delivery; chimeric antibodies; autoimmunity; immunity; tolerance; immunizations

\section{Introduction}

Dendritic cells (DC) take up, process, and present foreign and self-antigens to T cells, resulting in critical interactions that initiate and regulate specific immune responses. DC consist of two main populations, plasmacytoid (pDC) and conventional (cDC), which are further divided into the $\mathrm{CDC} 1$ and $\mathrm{CDC} 2$ subsets based on their developmental dependency on IRF8/Batf3 and IRF4/Notch2 transcription factors, respectively, and also their specific expression of multiple surface markers [1-6]. Whereas pDC express DC-SIGN, Siglec-H, B220, and Ly6c, murine cDC1 are characterized by specific expression of XCR1, and some cDC1 also express CD8 $\alpha$, DEC-205, BTLA, Langerin, Treml4, CD103, and Clec9a. In contrast, murine cDC2 express CD172a (SIRP $\alpha)$ and additionally DCIR2 and CD11b [3,4,7-9]. Many of these surface markers represent molecules that had been utilized for antigen-delivery strategies to the corresponding $\mathrm{cDC}$, the primary focus of this review, and $\mathrm{pDC}$, as discussed below (Figure 1).

Both human and murine DC develop from bone marrow-derived progenitors that disseminate throughout multiple immune and non-immune tissues and organs and have distinct phenotypic characteristics, as reviewed in $[5,6,10]$. In contrast to cDC, which are present at anatomical barriers such as the skin or intestines, and the associated lymphoid tissues that are exposed to microbiota, other $\mathrm{CDC}$, referred to here as "systemic" cDC, are present in secondary lymphoid organs, including the spleen and lymph nodes (LNs), and are not directly exposed to extrinsic environmental factors. Instead, these cDC constantly survey local and circulating antigens derived from parenchymal, interstitial, and other non-barrier tissues. Further, systemic cDC also present to T cells other relevant antigens, notably those derived from infectious pathogens as well as the antigens included in vaccines [11-13]. The $\mathrm{cDC}$ that are present in lymphoid organs either originate from the 
progenitors directly disseminating through the blood or from progenitors that first seed peripheral non-lymphoid tissues and then fully differentiate into cDC before migrating to lymphoid organs $[6,14]$. Such migratory cDC may ferry antigens from either healthy tissues or tumors and present these antigens to T cells directly, or instead, pass on the antigens to other $\mathrm{CDC}$ residing in the lymphoid tissues [11,15-28]. Overall, in contrast to the antigens that can become readily available at the anatomical barriers, the experimental administration of the antigens to systemic cDC has historically involved injections of substantial amounts of the relevant free peptides or proteins, often leading to non-specific effects $[9,29]$. Therefore, the development of antigen-delivery systems based on recombinant antibodies specific for CDC opened the door to precise and selective methods of antigen delivery and allowed for a rigorous analysis of the resulting impact on T cells. Additionally, a combination of the antigen-delivery methods with genetic models that alter the numbers or specific functions of CDC further broadened our understanding of the roles of various cDC populations [9]. Moreover, the methods of targeted antigen delivery to cDC became promising avenues for novel immunotherapeutic applications [30-34].
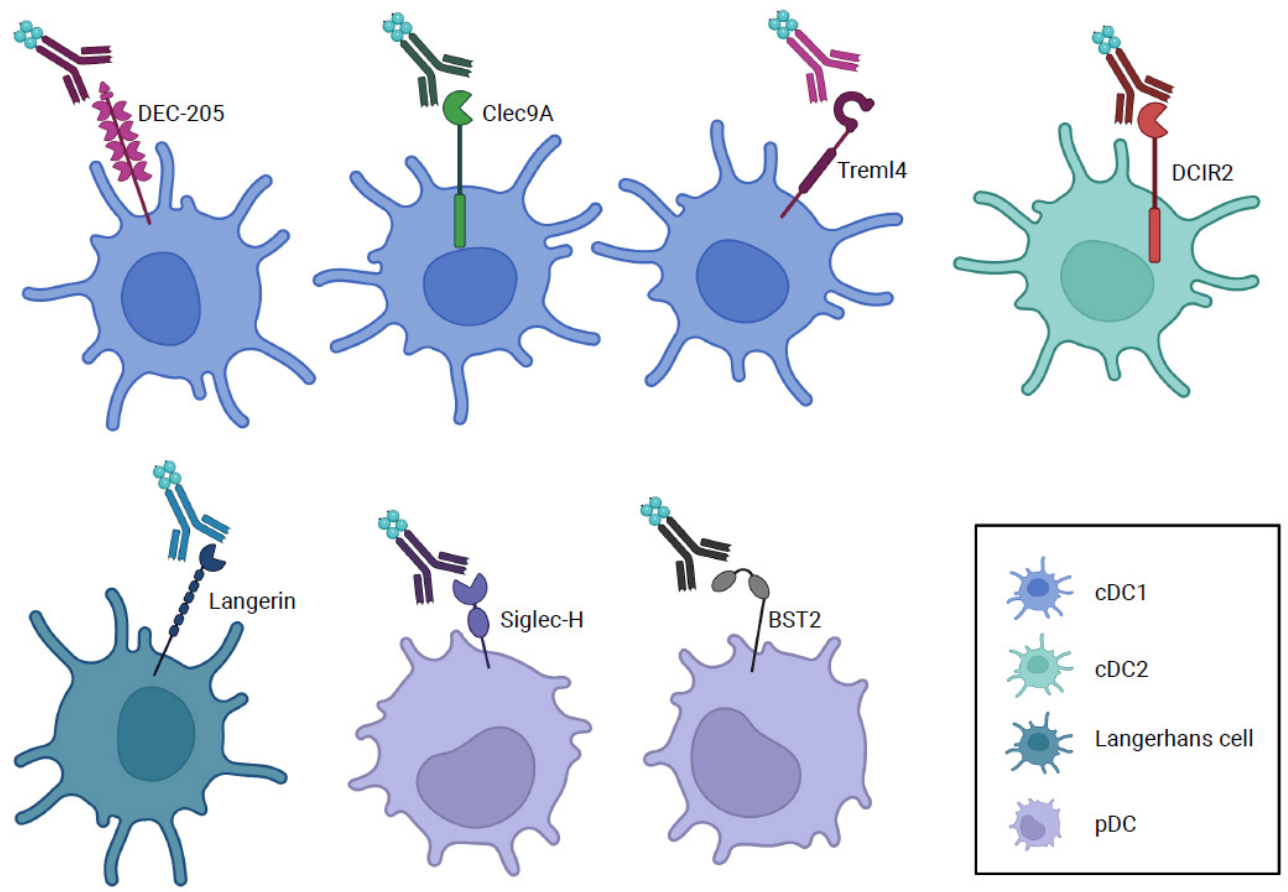

Figure 1. Various receptors used for targeted antigen delivery to dendritic cells. cDC: conventional dendritic cell; pDC: plasmacytoid dendritic cell.

Antigens can be delivered to various subsets of dendritic cells in vivo using recombinant chimeric antibodies to specific receptors that are present on such subsets.

\section{Anti-DEC-205-The First Recombinant Chimeric Antibody for In Vivo Antigen Delivery}

The first recombinant chimeric antibody ever designed to deliver specifically defined T cell antigens to DC targeted the endocytic receptor DEC-205 (DEC205, CD205, LY75). DEC-205 is expressed at high levels on CDC1 in the steady state, defined as the absence of specific pro-inflammatory stimuli [11,35-37]. Under pro-inflammatory conditions, such as in vivo after immunization using adjuvants or in vitro after specific activation, other immune cells, including germinal center B cells and cDC2, can also increase expression of DEC-205 [29,38-40]. However, in the steady state, DEC-205 mediates an efficient endocytic pathway, allowing for the robust processing and presentation of antigens specifically delivered to DEC-205 ${ }^{+}$cDC1 [29,32,41,42]. Further, antigens delivered through DEC-205 are presented both in the context of major histocompatibility complex class I (MHC-I) and MHC-II without causing other perceivable changes to cDC $[32,35,43]$. Therefore, DEC-205 
has become an ideal target for antigen-delivery strategies to cDC1 in the steady state and has allowed for a comprehensive analysis of the outcomes of $\mathrm{T}$ cell activation by cognate antigens presented by cDC [32,44-47] (Figure 2).
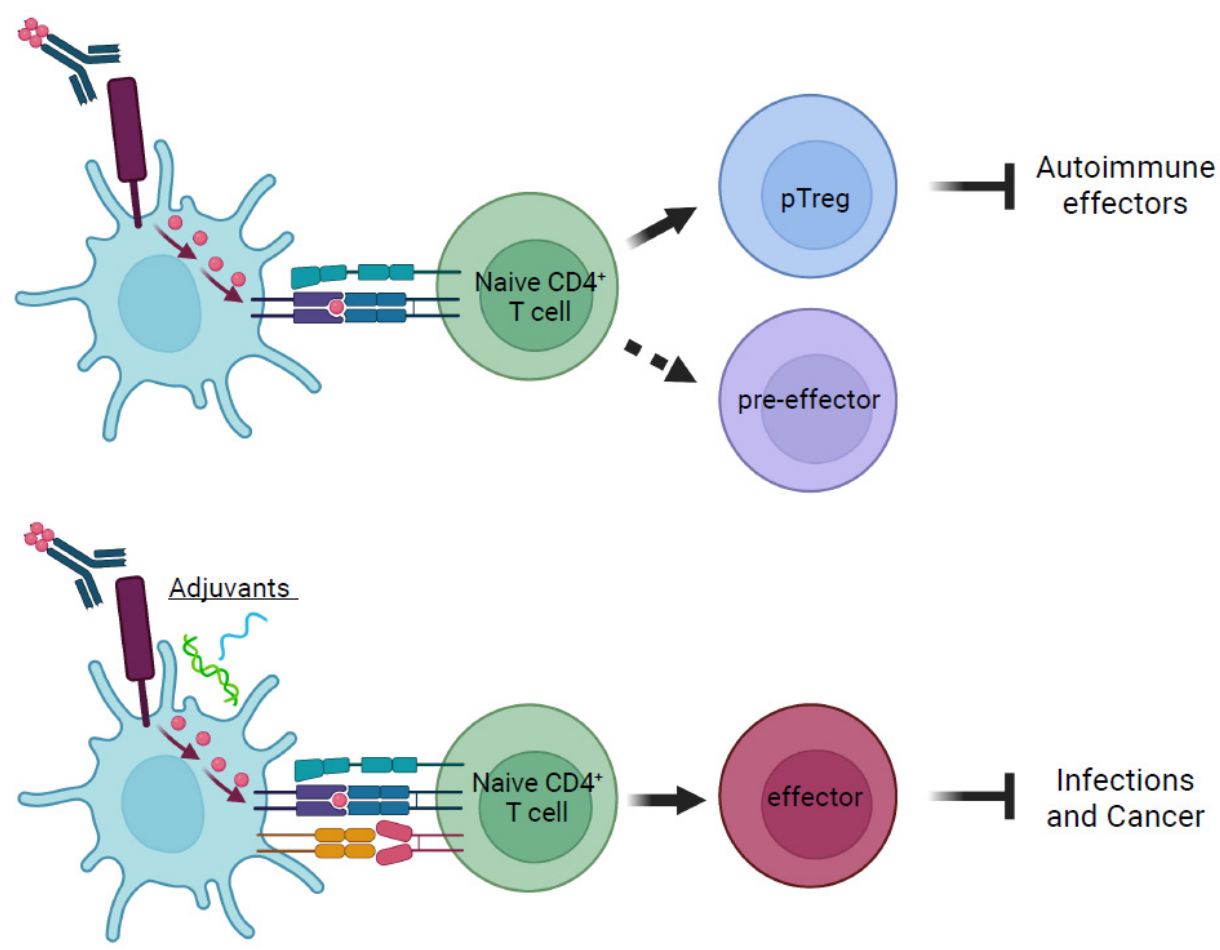

Figure 2. T cell outcomes of targeted antigen delivery to DC in the absence and presence of proinflammatory signals.

These early experiments helped to unequivocally establish that, in the steady state, the outcome of the initial CD4 ${ }^{+} \mathrm{T}$ cell antigenic stimulation by DC results in T cell tolerance [35]. By clarifying the functions of $\mathrm{CDC}$ in the steady state, these results helped to refute the original designation of such cDC as "immature" immune bystanders, as was initially assumed due to an apparent lack of $\mathrm{T}$ cell priming in the absence of pro-inflammatory stimuli $[9,29,35,48]$. Furthermore, by using MHC-I-restricted and cross-presented antigens, subsequent experiments extended the initially established tolerogenic functions of the DEC-205 ${ }^{+}$DCs to the induction of tolerance among CD8 ${ }^{+}$T cells [43]. Such tolerogenic functions of $\mathrm{cDC}$ also represent potential important therapeutic opportunities, and antiDEC-205-mediated delivery to CDC1 was subsequently harnessed for the prevention and mitigation of an autoimmune process. In these experiments, animals were treated with antiDEC-205-myelin oligodendrocyte glycoprotein $\left(\mathrm{MOG}_{35-55}\right)$ chimeric antibody (designated as anti-DEC-205-MOG or anti-DEC-MOG) to deliver the neural antigen MOG to cDC1 under non-inflammatory conditions, resulting in a prevention of specific autoimmune responses and disease symptoms of experimental autoimmune encephalomyelitis (EAE), a murine model of multiple sclerosis (MS) [36]. The effectiveness of targeting antigens to DEC-205 to promote antigen-specific immune tolerance and to ameliorate disease severity was subsequently extended to other models of autoimmune disease, including diabetes, inflammatory bowel disease (IBD), graft-versus-host disease (GVHD), and arthritis [49-54] (Table 1). 
Table 1. Summary of the different DC surface receptors used for delivery of specific antigens in different disease models.

\begin{tabular}{|c|c|c|c|}
\hline Receptor & Disease (Model) & Antigen(s) & Reference(s) \\
\hline \multirow{2}{*}{ BST2 } & Melanoma (B16-OVA) & OVA & [55] \\
\hline & Vaccinia-OVA Infection & OVA & [55] \\
\hline \multirow[t]{2}{*}{ DCIR2 } & Diabetes (non-obese diabetic) & $\begin{array}{l}\text { BDC2.5-stimulatory } \\
\text { mimetope }\end{array}$ & [56] \\
\hline & Melanoma (B16F10-OVA) & OVA & [57] \\
\hline \multirow{13}{*}{ DEC-205 } & $\begin{array}{l}\text { Arthritis } \\
\text { (proteoglycan-induced) }\end{array}$ & Cartilage proteoglycan & [52] \\
\hline & $\begin{array}{l}\text { Breast cancer (neu-expressing } \\
\text { NT2.5) }\end{array}$ & HER2/neu & [58] \\
\hline & $\begin{array}{l}\text { Diabetes } \\
\text { (INS-HA/TCR-HA transgenic) }\end{array}$ & Hemagglutinin (HA) & [54] \\
\hline & Diabetes (non-obese diabetic) & $\begin{array}{l}\text { Islet-specific glucose-6- } \\
\text { phosphatase catalytic } \\
\text { subunit-related protein }\end{array}$ & [49] \\
\hline & Diabetes (non-obese diabetic) & Proinsulin 2 & {$[50]$} \\
\hline & $\begin{array}{l}\text { Graft-versus-host disease (Skin } \\
\text { transplant) }\end{array}$ & Type XVII collagen & [53] \\
\hline & $\begin{array}{l}\text { Inflammatory Bowel Disease } \\
\text { (VILLIN-HA transgenic) }\end{array}$ & Hemagglutinin (HA) & [51] \\
\hline & Melanoma (B16F10 and RET) & gp100 & [59] \\
\hline & Melanoma (B16) & $\begin{array}{l}\text { Tyrosinase-related protein } 2 \\
\text { and gp100 }\end{array}$ & {$[60]$} \\
\hline & Melanoma (B16F10-OVA) & OVA & {$[57,61]$} \\
\hline & Multiple Sclerosis (EAE) & MOG & {$[36,46,47,62]$} \\
\hline & Vaccinia-OVA Infection & OVA & [61] \\
\hline & Yersinia pestis Infection & Yersinia pestis LcrV & {$[63,64]$} \\
\hline Langerin & Multiple Sclerosis (EAE) & MOG & [46] \\
\hline Siglec-H & Multiple Sclerosis (EAE) & MOG & [65] \\
\hline Treml4 & $\begin{array}{l}\text { Breast cancer } \\
\text { (neu-expressing NT2.5) }\end{array}$ & HER2/neu & [66] \\
\hline
\end{tabular}

DC: dendritic cells; OVA: ovalbumin; MOG: myelin oligodendrocyte glycoprotein.

Whereas in the absence of pro-inflammatory signals (steady state) presentation of antigens by $\mathrm{CDC}$ to $\mathrm{T}$ cells results in the formation of pTreg cells and also some other $\mathrm{T}$ cell types, such as pre-effectors, antigenic presentation in the presence of pro-inflammatory adjuvants leads to effector $\mathrm{T}$ cell responses.

In contrast to these tolerogenic mechanisms, the efficient priming of effector $\mathrm{T}$ cells by cDC in vivo requires sensing of additional signals, such as those relayed through specific pattern recognition receptors that recognize conserved pathogen components [6,67-71]. These signals result in a pro-immunogenic process that enhances specific functions of cDC and is generally referred to as "maturation", which results in altered expression of costimulatory molecules, MHCs, and cytokines, as well as other changes in CDC to facilitate enhanced effector T cell-priming under pro-inflammatory conditions [69,72,73]. Consistently, the activation of cDC1 through ligation of surface CD40 prevented a tolerogenic outcome of $\mathrm{T}$ cell activation and resulted in the priming of antigen-specific effector $\mathrm{T}$ cells [35]. Further, the targeting of antigens to DEC-205 has also been successfully applied as a promising vaccine approach in both infectious and tumor models. Administration of 
the adjuvant polyinosinic:polycytidylic acid (Poly(I:C)) together with recombinant antiDEC-205 antibodies linked with the Yersinia pestis virulence protein LcrV induced humoral responses as well as $\mathrm{T}$ helper 1 (Th1) $\mathrm{CD}^{+} \mathrm{T}$ cells in the lung [63,64]. Similarly, administration of anti-DEC-205-HIVgag-p24 in the presence of an anti-CD40 adjuvant led to Th1 responses as well as cross-presentation to $\mathrm{CD}^{+} \mathrm{T}$ cells [74]. In addition to eliciting immune responses against pathogens, the delivery of tumor-associated antigens (such as tyrosinase-related protein 2) or other antigens known to be involved in tumorigenesis (such as survivin) to DEC-205-expressing cells in the presence of co-administered adjuvants, such as $\mathrm{CpG}$, Poly(I:C), or anti-CD40, enhanced the anti-tumor $\mathrm{CD}^{+}$and $\mathrm{CD} 8^{+} \mathrm{T}$ cell responses and decreased the tumor burden $[57-61,75,76]$.

\section{Orchestrating Diverse Immune Responses by Delivering Antigens to Dendritic Cells in the Steady State}

The results of experiments that revealed priming of immune responses, resulting from combining antigen delivery to DEC-205 with the administration of adjuvants, reinforced the dogma of tolerogenic responses being induced in the steady state while immune responses were promoted under pro-inflammatory conditions $[9,29]$. However, it is important to note that the robust induction of tolerance by $\mathrm{CDC}$ in the steady state is not consistent with other experimental evidence that indicated an induction of effector $\mathrm{T}$ cells and autoimmunity, even in the absence of major pro-inflammatory perturbations in homeostasis [77-86]. Further, the crucial process of cancer immunosurveillance postulated to constantly remove cancerous cells arising under homeostatic conditions may be viewed as inconsistent with the predominantly tolerogenic outcomes of $\mathrm{T}$ cell activation mediated by CDC1 under homeostatic conditions $[87,88]$. Recent experiments utilizing anti-DEC-205mediated antigen delivery in the steady state have helped to clarify these conundrums. These results identified an active programming in the steady state by cDC1 of naïve CD4 ${ }^{+}$ $\mathrm{T}$ cells with specific epigenetic and transcriptional instructions, leading to an acquisition of T helper effector functions (Figure 2). Such "pre-effectors" activated in the steady state become poised for subsequent effector differentiation and, upon re-stimulation under non-skewing conditions in vitro or in vivo, readily express key factors such as IFN- $\gamma$ that then can trigger expression of T-bet, and possibly other effector master regulators [89]. These pre-effectors can contribute to initiation of the autoimmune responses, and any such pre-effectors specifically induced by tumor neo-antigens might also have a key role for cancer immunosurveillance $[89,90]$.

Such an induction of pre-effectors in the steady state necessitates the existence of dedicated pathways in $\mathrm{CDC}$ to promote specific mechanisms of tolerance that include inducing $\mathrm{T}$ cell anergy, $\mathrm{T}$ cell deletion, and a conversion of peripheral regulatory $\mathrm{T}$ cells (pTregs) $[9,11,91]$. Particularly, the pTregs that are de novo converted in response to specific self-antigens bestow a dominant and long-lasting tolerance to peripheral antigens that can ameliorate various autoimmune responses, therefore crucially complementing the immunological tolerance first initiated in the thymus $[9,11,92]$. Multiple cytokines, metabolites, and other key molecules, including transforming growth factor $\beta$ (TGF- $\beta$ ), retinoic acid (RA), IL-10, and CD39, help to initiate and further facilitate the conversion of pTregs [15,93-102]. Such induction of systemic pTregs is efficiently mediated in the steady state by the Batf3-dependent $\mathrm{CDC} 1$, corresponding to previously defined CD8 $\alpha^{+} \mathrm{DEC}-205^{+}$ CDC present both in LNs and spleen $[1,9,11,29,47]$. These tolerogenic $\mathrm{CDC} 1$ are further distinguished by their high expression of $\mathrm{B}$ and $\mathrm{T}$ lymphocyte associated/attenuator (BTLA), and such BTLA ${ }^{\text {hi }}$ CDC1 constitute the majority of splenic $\mathrm{CDC} 1$ in the steady state $[6,12,47]$. BTLA then engages herpesvirus entry mediator (HVEM) in CD4 ${ }^{+} \mathrm{T}$ cells to modulate the CD5-dependent resistance of developing pTregs to effector-differentiating cytokines such as IL-4, IL-6, and IFN- $\gamma[47,92,101,103]$. Therefore, functions of the BTLAHVEM-CD5 axis stabilize and promote the process of pTreg conversion [101]. Overall, these mechanisms mediated by BTLA ${ }^{\text {hi }} \mathrm{cDC} 1$ are crucial for a vigorous $\mathrm{pTreg}$ conversion, which is key to the de novo induction of specific peripheral tolerance. 


\section{Other Cell Surface Molecules Used for Antigen Delivery to Dendritic Cells}

The successful delivery of antigens via DEC-205 prompted the introduction of recombinant antibodies targeting other surface molecules present on $\mathrm{CDC}$ and $\mathrm{pDC}$, and many such antibodies used a similar design originated by the recombinant anti-DEC205 but utilized $\mathrm{V}$ regions from the original antibodies specific for the corresponding molecules $[9,45-47,55,65,66,74,104,105]$. In addition to recombinant chimeric anti-CD11c to deliver antigens to all murine $\mathrm{CDC}$, irrespectively of subsets, multiple other antigentargeting antibodies have been used. Langerin (CD207) is a transmembrane protein expressed on the cell surface of Langerhans cells as well as on some cDC1 of the spleen and skin, draining lymph nodes in mice, and has been identified on human Langerhans cells and tissue CDC2 [106-118]. Antigen-delivering anti-Langerin antibodies target antigens to Langerin ${ }^{+} \mathrm{CDC}$ of the spleen and peripheral lymph nodes and dermal Langerin ${ }^{+} \mathrm{CDC}$, resulting in lessened EAE symptom severity in a manner similar to that observed following administration of anti-DEC-205-MOG $[9,46,74,104]$. Trem-like 4 (Treml4) is a member of the "triggering receptor expressed on myeloid cells" family that binds apoptotic or necrotic cells and is expressed in mice, predominantly on $\mathrm{CDC} 1$ as well as splenic macrophages $[66,119]$. The targeting of diverse antigens to Treml $4^{+} \mathrm{CDC} 1$ by anti-Treml 4 antibodies elicited both $\mathrm{CD}^{+}$and $\mathrm{CD} 8^{+} \mathrm{T}$ cell responses, but the effects of antigen delivery on disease severity in various models, including tumor transplantation and $\mathrm{EAE}$, remain to be more fully elucidated $[46,66]$. C-type lectin domain family $9 \mathrm{~A}$ is an endocytic C-type lectin receptor that binds necrotic cells and is also known as dendritic cell natural killer lectin group receptor-1 (Clec9a, DNGR-1). It is primarily expressed by murine $\mathrm{cDC} 1$ and $\mathrm{pDC}$, human $\mathrm{cDC} 1$, and some B cells, and antigens taken up in a Clec9a-dependent manner can be presented on MHC-I and MHC-II [120-127]. Under steady state conditions, antigens delivered to cDC using anti-Clec9a chemically conjugated antibodies and presented on MHC-II prompted the differentiation of pTregs [44]. In contrast, antigen targeting Poly(I:C)-matured DC using recombinant anti-Clec9a antibodies resulted in Th1 CD4 ${ }^{+}$and $\mathrm{CD} 8^{+} \mathrm{T}$ cell priming comparable to that observed following administration of anti-DEC-205-Ag or anti-Langerin$\mathrm{Ag}[9,74]$. Targeting through $\mathrm{Clec} 9 \mathrm{a}$ in a humanized mouse system resulted in a powerful priming of $\mathrm{CD}^{+} \mathrm{T}$ cells [128].

Currently, fewer options exist for targeting antigens specific to the $\mathrm{CDC} 2$ lineage. DC inhibitory receptor 2 lectin (DCIR2) (also known as Clec4a4) is expressed by some murine splenic cDC2, while Clec4a (DCIR), the sole human DCIR family member, is more broadly expressed, including on pDC [45,129-134]. Therefore, antigens can be delivered to murine CDC2 using anti-DCIR2, and a targeted antigen delivery through DCIR2 was employed to induce pro-immunogenic immune responses, which resulted in desirable outcomes such as prolonged survival in tumor models $[45,56,57,133]$.

Sialic acid binding Ig-like lectin $\mathrm{H}$ (Siglec-H) and bone marrow stromal cell antigen 2 (BST2), which correlate with human pDC-expressed molecules, were successfully used for antigen delivery to murine $\mathrm{pDC}$, resulting in pro-immunogenic or tolerogenic $\mathrm{T}$ cell responses $[8,55,65,135-139]$. In the steady state, antigens delivered to pDCs blocked autoimmune reactions, whereas in the presence of an adjuvant, such antigen targeting may lead to antiviral and anti-tumor responses $[55,65]$.

\section{Translational Perspectives of Targeted Antigen Delivery to Dendritic Cells}

Humanized recombinant antibodies analogous to their murine counterparts described above have been considered as antigen-delivery vehicles in patients. Although the expression of human DEC-205 is not limited to CDC1, human CDC1 highly express DEC$205[140,141]$. The in vivo administration of anti-hDEC-205 antibodies fused to Epstein-Barr virus or human immunodeficiency (HIV) antigens together with the adjuvant Poly(I:C) elicited antiviral $\mathrm{T}$ cell responses [142-145]. Similarly, vaccination with anti-hDEC-205NY-ESO-1 tumor antigen in conjunction with Toll-like receptor (TLR) agonists elicited an anti-tumor immune response and tumor regression in some patients with multiple advanced malignancies refractory to other therapies $[146,147]$. Overall, the anti-DEC-205- 
mediated delivery of antigens from pathogens and tumors is likely to further render these recombinant antibodies as central to the design of new vaccine-based immunotherapies. In addition to full immunoglobulins, single-chain fragment variable region ( $\mathrm{scFv}$ ) and single-domain antibody ( $\mathrm{sdAb}$ ) have also been used for antigen delivery under multiple immune conditions $[9,33,59,148-153]$.

In addition to the applications against infections and tumors, the vast body of work obtained from the animal disease models described above suggests the targeted antigen delivery to tolerogenic $\mathrm{CDC} 1$ as possible new efficacious strategies for corresponding therapies in patients with autoimmune diseases, such as MS. Despite a substantial progress in developing new immunotherapies against MS, currently available immunotherapy protocols are only partially effective, and most of these approaches are burdened by side effects [30]. Therefore, the new approaches for immunomodulation of MS should specifically remove functions of offending immune cells without impairing immune responses against pathogens and tumors [30]. The neural inflammation responsible for neurological symptoms in MS and its animal disease model EAE results from the infiltration of nervous tissues by perivascular $\mathrm{CD}^{+} \mathrm{T}$ that gives rise to the Th1 and Th17-dependent autoimmune process [62,92,154,155]. Immunization with neural antigens, such as MOG, myelin basic protein (MBP), or proteolipid protein (PLP), leads to different variants of EAE that resemble the human progressive and relapsing-remitting forms of MS [92]. Previous research from multiple groups has shown the efficacy of the introduction of MOG, MBP, and PLP in a non-immunogenic context for blocking the subsequent induction of the corresponding forms of EAE [92,156,157]. However, a long-term administration of such antigens without control over which antigen-presenting cells (APCs) present them to T cells in vivo may not guarantee the certainty of the ultimate therapeutic results, and instead could lead to a generation of autoimmune pre-effectors and effectors [30]. Therefore, in addition to focusing on neural-derived antigens that are specifically recognized only by the corresponding encephalitogenic $\mathrm{T}$ cells, and thus no other $\mathrm{T}$ cells, such specific antigens should be delivered only in a "tolerogenic" context to ensure the specific elimination or functional inactivation of antigen-activated encephalitogenic $\mathrm{T}$ cells. These goals might be achieved by approaches that rely on transfers of autologous DC with tolerogenic functions induced in vitro, and similar approaches are now in clinical trials [9,11,30]. However, such approaches are going to require costly treatments with individually prepared DC for each patient while not guaranteeing the functional activity of such transferred DC. Instead, the direct delivery of antigens to $\mathrm{CDC}$ with specialized tolerogenic functions in vivo would allow for a better control of the ensuing immunological processes and maximize the de novo induction of antigen-specific pTregs [30-32]. In general, Tregs play a crucial role in protection and recovery from EAE and MS by suppressing autoreactive $\mathrm{T}$ cells, and functional defects of Tregs have been implicated in the pathogenesis of MS [92]. It is now well established that neuroinflammation can be ameliorated or even completely prevented by antigen-specific pTregs that are induced systemically in the secondary immune organs in response to the relevant neuronal antigens, and confer a long-lasting tolerance that can suppress local effector responses in the CNS and prevent EAE [47,62,92]. Therefore, strategies focused on delivering the neural antigens specifically to tolerogenic $\mathrm{CDC}$, such as BTLA $^{\text {hi }}$ cDC1, could offer the most effective means for therapeutically relevant induction of tolerance. Further manipulations of these specific BTLA-mediated mechanisms could open new avenues for immunomodulation by manipulating the specific formation and functions of the relevant pTregs. These approaches allow for highly specific immunomodulation that is focused only on autoreactive encephalitogenic T cells, without impairing other immune responses, and would therefore be more selective and have fewer side effects. Further, such approaches could be extended to other diseases. Overall, antigen delivery through DEC-205 and other CDC surface proteins has allowed for a comprehensive analysis and utilization of the outcomes of T cell activation and priming by specific cDC subsets. Therefore, future applications should carefully consider the specific advantages and disadvantages of delivering antigens to defined $\mathrm{cDC}$ subsets with diverse functions. 

Author Contributions: Writing-original draft preparation, J.B. and D.H. All authors have read and
agreed to the published version of the manuscript.

Funding: This research received no external funding.

Acknowledgments: Figures were created with BioRender.

Conflicts of Interest: The authors declare no conflict of interest.

\section{References}

1. Guilliams, M.; Ginhoux, F.; Jakubzick, C.; Naik, S.H.; Onai, N.; Schraml, B.U.; Segura, E.; Tussiwand, R.; Yona, S. Dendritic cells, monocytes and macrophages: A unified nomenclature based on ontogeny. Nat. Rev. Immunol. 2014, 14, 571-578. [CrossRef] [PubMed]

2. Swiecki, M.; Colonna, M. The multifaceted biology of plasmacytoid dendritic cells. Nat. Rev. Immunol. 2015, 15, 471. [CrossRef] [PubMed]

3. Durai, V.; Murphy, K.M. Functions of Murine Dendritic Cells. Immunity 2016, 45, 719-736. [CrossRef] [PubMed]

4. Guilliams, M.; Dutertre, C.A.; Scott, C.L.; McGovern, N.; Sichien, D.; Chakarov, S.; Van Gassen, S.; Chen, J.; Poidinger, M.; De Prijck, S.; et al. Unsupervised High-Dimensional Analysis Aligns Dendritic Cells across Tissues and Species. Immunity 2016, 45, 669-684. [CrossRef]

5. Anderson, D.A.; Dutertre, C.-A.; Ginhoux, F.; Murphy, K.M. Genetic models of human and mouse dendritic cell development and function. Nat. Rev. Immunol. 2021, 21, 101-115. [CrossRef]

6. Cabeza-Cabrerizo, M.; Cardoso, A.; Minutti, C.M.; da Costa, M.P.; Reis, E.S.C. Dendritic Cells Revisited. Annu. Rev. Immunol. 2021, 39, 131-166. [CrossRef]

7. Merad, M.; Sathe, P.; Helft, J.; Miller, J.; Mortha, A. The dendritic cell lineage: Ontogeny and function of dendritic cells and their subsets in the steady state and the inflamed setting. Annu. Rev. Immunol. 2013, 31, 563-604. [CrossRef]

8. Zhang, J.; Raper, A.; Sugita, N.; Hingorani, R.; Salio, M.; Palmowski, M.J.; Cerundolo, V.; Crocker, P.R. Characterization of Siglec-H as a novel endocytic receptor expressed on murine plasmacytoid dendritic cell precursors. Blood 2006, 107, 3600-3608. [CrossRef]

9. Iberg, C.A.; Jones, A.; Hawiger, D. Dendritic Cells As Inducers of Peripheral Tolerance. Trends Immunol. 2017, 38, 793-804. [CrossRef]

10. Murphy, T.L.; Grajales-Reyes, G.E.; Wu, X.; Tussiwand, R.; Briseno, C.G.; Iwata, A.; Kretzer, N.M.; Durai, V.; Murphy, K.M. Transcriptional Control of Dendritic Cell Development. Annu. Rev. Immunol. 2016, 34, 93-119. [CrossRef]

11. Iberg, C.A.; Hawiger, D. Natural and Induced Tolerogenic Dendritic Cells. J. Immunol. 2020, 204, 733-744. [CrossRef] [PubMed]

12. Eisenbarth, S.C. Dendritic cell subsets in T cell programming: Location dictates function. Nat. Rev. Immunol. 2019, 19, 89-103. [CrossRef] [PubMed]

13. Langlet, C.; Tamoutounour, S.; Henri, S.; Luche, H.; Ardouin, L.; Grégoire, C.; Malissen, B.; Guilliams, M. CD64 expression distinguishes monocyte-derived and conventional dendritic cells and reveals their distinct role during intramuscular immunization. J. Immunol. 2012, 188, 1751-1760. [CrossRef] [PubMed]

14. Sichien, D.; Lambrecht, B.N.; Guilliams, M.; Scott, C.L. Development of conventional dendritic cells: From common bone marrow progenitors to multiple subsets in peripheral tissues. Mucosal Immunol. 2017, 10, 831-844. [CrossRef]

15. Ardouin, L.; Luche, H.; Chelbi, R.; Carpentier, S.; Shawket, A.; Montanana Sanchis, F.; Santa Maria, C.; Grenot, P.; Alexandre, Y.; Gregoire, C.; et al. Broad and Largely Concordant Molecular Changes Characterize Tolerogenic and Immunogenic Dendritic Cell Maturation in Thymus and Periphery. Immunity 2016, 45, 305-318. [CrossRef]

16. Azukizawa, H.; Dohler, A.; Kanazawa, N.; Nayak, A.; Lipp, M.; Malissen, B.; Autenrieth, I.; Katayama, I.; Riemann, M.; Weih, F.; et al. Steady state migratory RelB+ langerin+ dermal dendritic cells mediate peripheral induction of antigen-specific CD4+ CD25+ Foxp3+ regulatory T cells. Eur. J. Immunol. 2011, 41, 1420-1434. [CrossRef] [PubMed]

17. Gurevich, I.; Feferman, T.; Milo, I.; Tal, O.; Golani, O.; Drexler, I.; Shakhar, G. Active dissemination of cellular antigens by DCs facilitates CD8(+) T-cell priming in lymph nodes. Eur. J. Immunol. 2017, 47, 1802-1818. [CrossRef]

18. Allan, R.S.; Waithman, J.; Bedoui, S.; Jones, C.M.; Villadangos, J.A.; Zhan, Y.; Lew, A.M.; Shortman, K.; Heath, W.R.; Carbone, F.R. Migratory dendritic cells transfer antigen to a lymph node-resident dendritic cell population for efficient CTL priming. Immunity 2006, 25, 153-162. [CrossRef]

19. Guilliams, M.; Crozat, K.; Henri, S.; Tamoutounour, S.; Grenot, P.; Devilard, E.; de Bovis, B.; Alexopoulou, L.; Dalod, M.; Malissen, B. Skin-draining lymph nodes contain dermis-derived CD103(-) dendritic cells that constitutively produce retinoic acid and induce Foxp3(+) regulatory T cells. Blood 2010, 115, 1958-1968. [CrossRef]

20. Baratin, M.; Foray, C.; Demaria, O.; Habbeddine, M.; Pollet, E.; Maurizio, J.; Verthuy, C.; Davanture, S.; Azukizawa, H.; FloresLangarica, A.; et al. Homeostatic NF-kappaB Signaling in Steady-State Migratory Dendritic Cells Regulates Immune Homeostasis and Tolerance. Immunity 2015, 42, 627-639. [CrossRef]

21. Scheinecker, C.; McHugh, R.; Shevach, E.M.; Germain, R.N. Constitutive presentation of a natural tissue autoantigen exclusively by dendritic cells in the draining lymph node. J. Exp. Med. 2002, 196, 1079-1090. [CrossRef] [PubMed] 
22. Inaba, K.; Turley, S.; Yamaide, F.; Iyoda, T.; Mahnke, K.; Inaba, M.; Pack, M.; Subklewe, M.; Sauter, B.; Sheff, D.; et al. Efficient presentation of phagocytosed cellular fragments on the major histocompatibility complex class II products of dendritic cells. J. Exp. Med. 1998, 188, 2163-2173. [CrossRef] [PubMed]

23. Vitali, C.; Mingozzi, F.; Broggi, A.; Barresi, S.; Zolezzi, F.; Bayry, J.; Raimondi, G.; Zanoni, I.; Granucci, F. Migratory, and not lymphoid-resident, dendritic cells maintain peripheral self-tolerance and prevent autoimmunity via induction of iTreg cells. Blood 2012, 120, 1237-1245. [CrossRef] [PubMed]

24. Ruhland, M.K.; Roberts, E.W.; Cai, E.; Mujal, A.M.; Marchuk, K.; Beppler, C.; Nam, D.; Serwas, N.K.; Binnewies, M.; Krummel, M.F. Visualizing Synaptic Transfer of Tumor Antigens among Dendritic Cells. Cancer Cell 2020, 37, 786-799.e785. [CrossRef]

25. Harimoto, H.; Shimizu, M.; Nakagawa, Y.; Nakatsuka, K.; Wakabayashi, A.; Sakamoto, C.; Takahashi, H. Inactivation of tumor-specific CD8(+) CTLs by tumor-infiltrating tolerogenic dendritic cells. Immunol. Cell. Biol. 2013, 91, 545-555. [CrossRef]

26. Wang, Y.; Du, X.; Wei, J.; Long, L.; Tan, H.; Guy, C.; Dhungana, Y.; Qian, C.; Neale, G.; Fu, Y.X.; et al. LKB1 orchestrates dendritic cell metabolic quiescence and anti-tumor immunity. Cell Res. 2019, 29, 391-405. [CrossRef]

27. Maier, B.; Leader, A.M.; Chen, S.T.; Tung, N.; Chang, C.; LeBerichel, J.; Chudnovskiy, A.; Maskey, S.; Walker, L.; Finnigan, J.P.; et al. A conserved dendritic-cell regulatory program limits antitumour immunity. Nature 2020, 580, 257-262. [CrossRef]

28. Ghiringhelli, F.; Puig, P.E.; Roux, S.; Parcellier, A.; Schmitt, E.; Solary, E.; Kroemer, G.; Martin, F.; Chauffert, B.; Zitvogel, L. Tumor cells convert immature myeloid dendritic cells into TGF-beta-secreting cells inducing CD4+CD25+ regulatory T cell proliferation. J. Exp. Med. 2005, 202, 919-929. [CrossRef]

29. Steinman, R.M.; Hawiger, D.; Nussenzweig, M.C. Tolerogenic dendritic cells. Annu. Rev. Immunol. 2003, 21, 685-711. [CrossRef]

30. Bourque, J.; Hawiger, D. Current and Future Immunotherapies for Multiple Sclerosis. Mo Med. 2021, 118, $334-339$.

31. Iberg, C.A.; Hawiger, D. Targeting Dendritic Cells with Antigen-Delivering Antibodies for Amelioration of Autoimmunity in Animal Models of Multiple Sclerosis and Other Autoimmune Diseases. Antibodies 2020, 9, 23. [CrossRef] [PubMed]

32. Iberg, C.A.; Hawiger, D. Advancing immunomodulation by in vivo antigen delivery to DEC-205 and other cell surface molecules using recombinant chimeric antibodies. Int. Immunopharmacol. 2019, 73, 575-580. [CrossRef] [PubMed]

33. Lehmann, C.H.; Heger, L.; Heidkamp, G.F.; Baranska, A.; Luhr, J.J.; Hoffmann, A.; Dudziak, D. Direct Delivery of Antigens to Dendritic Cells via Antibodies Specific for Endocytic Receptors as a Promising Strategy for Future Therapies. Vaccines 2016, 4, 8. [CrossRef] [PubMed]

34. Wculek, S.K.; Cueto, F.J.; Mujal, A.M.; Melero, I.; Krummel, M.F.; Sancho, D. Dendritic cells in cancer immunology and immunotherapy. Nat. Rev. Immunol. 2019, 20, 7-24. [CrossRef] [PubMed]

35. Hawiger, D.; Inaba, K.; Dorsett, Y.; Guo, M.; Mahnke, K.; Rivera, M.; Ravetch, J.V.; Steinman, R.M.; Nussenzweig, M.C. Dendritic cells induce peripheral T cell unresponsiveness under steady state conditions in vivo. J. Exp. Med. 2001, 194, 769-779. [CrossRef] [PubMed]

36. Hawiger, D.; Masilamani, R.F.; Bettelli, E.; Kuchroo, V.K.; Nussenzweig, M.C. Immunological unresponsiveness characterized by increased expression of CD5 on peripheral T cells induced by dendritic cells in vivo. Immunity 2004, 20, 695-705. [CrossRef] [PubMed]

37. Steinman, R.M.; Hawiger, D.; Liu, K.; Bonifaz, L.; Bonnyay, D.; Mahnke, K.; Iyoda, T.; Ravetch, J.; Dhodapkar, M.; Inaba, K.; et al. Dendritic Cell Function in Vivo during the Steady State: A Role in Peripheral Tolerance. Ann. N. Y. Acad. Sci. 2003, 987, 15-25. [CrossRef] [PubMed]

38. Pasqual, G.; Angelini, A.; Victora, G.D. Triggering positive selection of germinal center B cells by antigen targeting to DEC-205. Methods Mol. Biol. 2015, 1291, 125-134. [CrossRef] [PubMed]

39. Kamphorst, A.O.; Guermonprez, P.; Dudziak, D.; Nussenzweig, M.C. Route of antigen uptake differentially impacts presentation by dendritic cells and activated monocytes. J. Immunol. 2010, 185, 3426-3435. [CrossRef] [PubMed]

40. McLellan, A.D.; Kapp, M.; Eggert, A.; Linden, C.; Bommhardt, U.; Brocker, E.-B.; Kammerer, U.; Kampgen, E. Anatomic location and T-cell stimulatory functions of mouse dendritic cell subsets defined by CD4 and CD8 expression. Blood 2002, 99, 2084-2093. [CrossRef] [PubMed]

41. Jiang, W.; Swiggard, W.J.; Heufler, C.; Peng, M.; Mirza, A.; Steinman, R.M.; Nussenzweig, M.C. The receptor DEC-205 expressed by dendritic cells and thymic epithelial cells is involved in antigen processing. Nature 1995, 375, 151-155. [CrossRef] [PubMed]

42. Mahnke, K.; Guo, M.; Lee, S.; Sepulveda, H.; Swain, S.L.; Nussenzweig, M.; Steinman, R.M. The dendritic cell receptor for endocytosis, DEC-205, can recycle and enhance antigen presentation via major histocompatibility complex class II-positive lysosomal compartments. J. Cell Biol. 2000, 151, 673-684. [CrossRef] [PubMed]

43. Bonifaz, L.; Bonnyay, D.; Mahnke, K.; Rivera, M.; Nussenzweig, M.C.; Steinman, R.M. Efficient Targeting of Protein Antigen to the Dendritic Cell Receptor DEC-205 in the Steady State Leads to Antigen Presentation on Major Histocompatibility Complex Class I Products and Peripheral CD8(+) T Cell Tolerance. J. Exp. Med. 2002, 196, 1627-1638. [CrossRef] [PubMed]

44. Joffre, O.P.; Sancho, D.; Zelenay, S.; Keller, A.M.; Sousa, C.R. Efficient and versatile manipulation of the peripheral CD4+ T-cell compartment by antigen targeting to DNGR-1/CLEC9A. Eur. J. Immunol. 2010, 40, 1255-1265. [CrossRef] [PubMed]

45. Dudziak, D.; Kamphorst, A.O.; Heidkamp, G.F.; Buchholz, V.R.; Trumpfheller, C.; Yamazaki, S.; Cheong, C.; Liu, K.; Lee, H.W.; Park, C.G.; et al. Differential antigen processing by dendritic cell subsets in vivo. Science 2007, 315, 107-111. [CrossRef] [PubMed]

46. Idoyaga, J.; Fiorese, C.; Zbytnuik, L.; Lubkin, A.; Miller, J.; Malissen, B.; Mucida, D.; Merad, M.; Steinman, R.M. Specialized role of migratory dendritic cells in peripheral tolerance induction. J. Clin. Investig. 2013, 123, 844-854. [CrossRef] [PubMed] 
47. Jones, A.; Bourque, J.; Kuehm, L.; Opejin, A.; Teague, R.M.; Gross, C.; Hawiger, D. Immunomodulatory Functions of BTLA and HVEM Govern Induction of Extrathymic Regulatory T Cells and Tolerance by Dendritic Cells. Immunity 2016, 45, 1066-1077. [CrossRef]

48. Steinman, R.M. Dendritic cells and immune-based therapies. Exp. Hematol. 1996, 24, 859-862.

49. Mukherjee, G.; Geliebter, A.; Babad, J.; Santamaria, P.; Serreze, D.V.; Freeman, G.J.; Tarbell, K.V.; Sharpe, A.; DiLorenzo, T.P. DEC-205-mediated antigen targeting to steady-state dendritic cells induces deletion of diabetogenic CD8(+) T cells independently of PD-1 and PD-L1. Int. Immunol. 2013, 25, 651-660. [CrossRef]

50. Petzold, C.; Riewaldt, J.; Koenig, T.; Schallenberg, S.; Kretschmer, K. Dendritic cell-targeted pancreatic beta-cell antigen leads to conversion of self-reactive CD4(+) T cells into regulatory T cells and promotes immunotolerance in NOD mice. Rev. Diabet. Stud. 2010, 7, 47-61. [CrossRef]

51. Wadwa, M.; Klopfleisch, R.; Buer, J.; Westendorf, A.M. Targeting Antigens to Dec-205 on Dendritic Cells Induces Immune Protection in Experimental Colitis in Mice. Eur. J. Microbiol. Immunol. 2016, 6, 1-8. [CrossRef]

52. Spiering, R.; Margry, B.; Keijzer, C.; Petzold, C.; Hoek, A.; Wagenaar-Hilbers, J.; van der Zee, R.; van Eden, W.; Kretschmer, K.; Broere, F. DEC205+ Dendritic Cell-Targeted Tolerogenic Vaccination Promotes Immune Tolerance in Experimental Autoimmune Arthritis. J. Immunol. 2015, 194, 4804-4813. [CrossRef] [PubMed]

53. Ettinger, M.; Gratz, I.K.; Gruber, C.; Hauser-Kronberger, C.; Johnson, T.S.; Mahnke, K.; Thalhamer, J.; Hintner, H.; Peckl-Schmid, D.; Bauer, J.W. Targeting of the hNC16A collagen domain to dendritic cells induces tolerance to human type XVII collagen. Exp. Dermatol. 2012, 21, 395-398. [CrossRef]

54. Bruder, D.; Westendorf, A.M.; Hansen, W.; Prettin, S.; Gruber, A.D.; Qian, Y.; von Boehmer, H.; Mahnke, K.; Buer, J. On the edge of autoimmunity: T-cell stimulation by steady-state dendritic cells prevents autoimmune diabetes. Diabetes 2005, 54, 3395-3401. [CrossRef] [PubMed]

55. Loschko, J.; Schlitzer, A.; Dudziak, D.; Drexler, I.; Sandholzer, N.; Bourquin, C.; Reindl, W.; Krug, A.B. Antigen delivery to plasmacytoid dendritic cells via BST2 induces protective T cell-mediated immunity. J. Immunol. 2011, 186, 6718-6725. [CrossRef] [PubMed]

56. Price, J.D.; Hotta-Iwamura, C.; Zhao, Y.; Beauchamp, N.M.; Tarbell, K.V. DCIR2+ cDC2 DCs and Zbtb32 Restore CD4+ T-Cell Tolerance and Inhibit Diabetes. Diabetes 2015, 64, 3521-3531. [CrossRef]

57. Neubert, K.; Lehmann, C.H.; Heger, L.; Baranska, A.; Staedtler, A.M.; Buchholz, V.R.; Yamazaki, S.; Heidkamp, G.F.; Eissing, N.; Zebroski, H.; et al. Antigen delivery to CD11c+CD8- dendritic cells induces protective immune responses against experimental melanoma in mice in vivo. J. Immunol. 2014, 192, 5830-5838. [CrossRef]

58. Wang, B.; Zaidi, N.; He, L.Z.; Zhang, L.; Kuroiwa, J.M.; Keler, T.; Steinman, R.M. Targeting of the non-mutated tumor antigen HER2/neu to mature dendritic cells induces an integrated immune response that protects against breast cancer in mice. Breast Cancer Res. 2012, 14, R39. [CrossRef]

59. Johnson, T.S.; Mahnke, K.; Storn, V.; Schonfeld, K.; Ring, S.; Nettelbeck, D.M.; Haisma, H.J.; Le Gall, F.; Kontermann, R.E.; Enk A.H. Inhibition of melanoma growth by targeting of antigen to dendritic cells via an anti-DEC-205 single-chain fragment variable molecule. Clin. Cancer Res. 2008, 14, 8169-8177. [CrossRef]

60. Mahnke, K.; Qian, Y.; Fondel, S.; Brueck, J.; Becker, C.; Enk, A.H. Targeting of antigens to activated dendritic cells in vivo cures metastatic melanoma in mice. Cancer Res. 2005, 65, 7007-7012. [CrossRef]

61. Bonifaz, L.C.; Bonnyay, D.P.; Charalambous, A.; Darguste, D.I.; Fujii, S.; Soares, H.; Brimnes, M.K.; Moltedo, B.; Moran, T.M.; Steinman, R.M. In vivo targeting of antigens to maturing dendritic cells via the DEC-205 receptor improves T cell vaccination. J. Exp. Med. 2004, 199, 815-824. [CrossRef] [PubMed]

62. Jones, A.; Opejin, A.; Henderson, J.G.; Gross, C.; Jain, R.; Epstein, J.A.; Flavell, R.A.; Hawiger, D. Peripherally Induced Tolerance Depends on Peripheral Regulatory T Cells That Require Hopx To Inhibit Intrinsic IL-2 Expression. J. Immunol. 2015, 195, 1489-1497. [CrossRef] [PubMed]

63. Do, Y.; Didierlaurent, A.M.; Ryu, S.; Koh, H.; Park, C.G.; Park, S.; Perlin, D.S.; Powell, B.S.; Steinman, R.M. Induction of pulmonary mucosal immune responses with a protein vaccine targeted to the DEC-205/CD205 receptor. Vaccine 2012, 30, 6359-6367. [CrossRef] [PubMed]

64. Do, Y.; Koh, H.; Park, C.G.; Dudziak, D.; Seo, P.; Mehandru, S.; Choi, J.H.; Cheong, C.; Park, S.; Perlin, D.S.; et al. Targeting of LcrV virulence protein from Yersinia pestis to dendritic cells protects mice against pneumonic plague. Eur. J. Immunol. 2010, 40, 2791-2796. [CrossRef]

65. Loschko, J.; Heink, S.; Hackl, D.; Dudziak, D.; Reindl, W.; Korn, T.; Krug, A.B. Antigen targeting to plasmacytoid dendritic cells via Siglec-H inhibits Th cell-dependent autoimmunity. J. Immunol. 2011, 187, 6346-6356. [CrossRef]

66. Hemmi, H.; Zaidi, N.; Wang, B.; Matos, I.; Fiorese, C.; Lubkin, A.; Zbytnuik, L.; Suda, K.; Zhang, K.; Noda, M.; et al. Treml4, an Ig superfamily member, mediates presentation of several antigens to T cells in vivo, including protective immunity to HER2 protein. J. Immunol. 2012, 188, 1147-1155. [CrossRef]

67. Coquerelle, C.; Moser, M. DC subsets in positive and negative regulation of immunity. Immunol. Rev. 2010, 234, 317-334. [CrossRef]

68. Steinman, R.M. Decisions about dendritic cells: Past, present, and future. Annu. Rev. Immunol. 2012, 30, 1-22. [CrossRef]

69. Mellman, I. Dendritic cells: Master regulators of the immune response. Cancer Immunol. Res. 2013, 1, 145-149. [CrossRef] 
70. Iwasaki, A.; Medzhitov, R. Control of adaptive immunity by the innate immune system. Nat. Immunol. 2015, 16, $343-353$. [CrossRef]

71. Janeway, C.A., Jr.; Medzhitov, R. Innate immune recognition. Annu. Rev. Immunol. 2002, 20, 197-216. [CrossRef] [PubMed]

72. Schuler, G.; Steinman, R.M. Murine epidermal Langerhans cells mature into potent immunostimulatory dendritic cells in vitro. J. Exp. Med. 1985, 161, 526-546. [CrossRef] [PubMed]

73. Dalod, M.; Chelbi, R.; Malissen, B.; Lawrence, T. Dendritic cell maturation: Functional specialization through signaling specificity and transcriptional programming. EMBO J. 2014, 33, 1104-1116. [CrossRef] [PubMed]

74. Idoyaga, J.; Lubkin, A.; Fiorese, C.; Lahoud, M.H.; Caminschi, I.; Huang, Y.; Rodriguez, A.; Clausen, B.E.; Park, C.G.; Trumpfheller, C.; et al. Comparable T helper 1 (Th1) and CD8 T-cell immunity by targeting HIV gag p24 to CD8 dendritic cells within antibodies to Langerin, DEC205, and Clec9A. Proc. Natl. Acad. Sci. USA 2011, 108, 2384-2389. [CrossRef]

75. Charalambous, A.; Oks, M.; Nchinda, G.; Yamazaki, S.; Steinman, R.M. Dendritic cell targeting of survivin protein in a xenogeneic form elicits strong CD4+ T cell immunity to mouse survivin. J. Immunol. 2006, 177, 8410-8421. [CrossRef]

76. Wang, B.; Kuroiwa, J.M.; He, L.Z.; Charalambous, A.; Keler, T.; Steinman, R.M. The human cancer antigen mesothelin is more efficiently presented to the mouse immune system when targeted to the DEC-205/CD205 receptor on dendritic cells. Ann. N. Y. Acad. Sci. 2009, 1174, 6-17. [CrossRef]

77. Fuertes, M.B.; Kacha, A.K.; Kline, J.; Woo, S.-R.; Kranz, D.M.; Murphy, K.M.; Gajewski, T.F. Host type I IFN signals are required for antitumor CD8+ T cell responses through CD8 $\alpha+$ dendritic cells. J. Exp. Med. 2011, 208, 2005-2016. [CrossRef]

78. Alspach, E.; Lussier, D.M.; Miceli, A.P.; Kizhvatov, I.; DuPage, M.; Luoma, A.M.; Meng, W.; Lichti, C.F.; Esaulova, E.; Vomund A.N.; et al. MHC-II neoantigens shape tumour immunity and response to immunotherapy. Nature 2019, 574, 696-701. [CrossRef]

79. Ferris, S.T.; Durai, V.; Wu, R.; Theisen, D.J.; Ward, J.P.; Bern, M.D.; Davidson, J.T.t.; Bagadia, P.; Liu, T.; Briseno, C.G.; et al. cDC1 prime and are licensed by CD4(+) T cells to induce anti-tumour immunity. Nature 2020, 584, 624-629. [CrossRef]

80. Mattiuz, R.; Brousse, C.; Ambrosini, M.; Cancel, J.-C.; Bessou, G.; Mussard, J.; Sanlaville, A.; Caux, C.; Bendriss-Vermare, N.; Valladeau-Guilemond, J.; et al. Type 1 conventional dendritic cells and interferons are required for spontaneous CD4+ and CD8+ T-cell protective responses to breast cancer. Clin. Transl. Immunol. 2021, 10, e1305. [CrossRef]

81. Sedlacek, A.L.; Younker, T.P.; Zhou, Y.J.; Borghesi, L.; Shcheglova, T.; Mandoiu, I.I.; Binder, R.J. CD91 on dendritic cells governs immunosurveillance of nascent, emerging tumors. JCI Insight 2019, 4, e127239. [CrossRef] [PubMed]

82. Huang, C.T.; Huso, D.L.; Lu, Z.; Wang, T.; Zhou, G.; Kennedy, E.P.; Drake, C.G.; Morgan, D.J.; Sherman, L.A.; Higgins, A.D.; et al CD4+ T cells pass through an effector phase during the process of in vivo tolerance induction. J. Immunol. 2003, 170, 3945-3953. [CrossRef] [PubMed]

83. Long, M.; Slaiby, A.M.; Wu, S.; Hagymasi, A.T.; Mihalyo, M.A.; Bandyopadhyay, S.; Vella, A.T.; Adler, A.J. Histone acetylation at the Ifng promoter in tolerized CD4 cells is associated with increased IFN-gamma expression during subsequent immunization to the same antigen. J. Immunol. 2007, 179, 5669-5677. [CrossRef] [PubMed]

84. Kawabe, T.; Jankovic, D.; Kawabe, S.; Huang, Y.; Lee, P.H.; Yamane, H.; Zhu, J.; Sher, A.; Germain, R.N.; Paul, W.E. Memoryphenotype CD4(+) T cells spontaneously generated under steady-state conditions exert innate TH1-like effector function. Sci. Immunol. 2017, 2, eaam9304. [CrossRef]

85. Gossel, G.; Hogan, T.; Cownden, D.; Seddon, B.; Yates, A.J. Memory CD4 T cell subsets are kinetically heterogeneous and replenished from naive $\mathrm{T}$ cells at high levels. elife 2017, 6, e23013. [CrossRef]

86. Vokali, E.; Yu, S.S.; Hirosue, S.; Rincon-Restrepo, M.; Duraes, F.V.; Scherer, S.; Corthesy-Henrioud, P.; Kilarski, W.W.; Mondino, A.; Zehn, D.; et al. Lymphatic endothelial cells prime naive CD8(+) T cells into memory cells under steady-state conditions. Nat. Commun. 2020, 11, 538. [CrossRef]

87. Dunn, G.P.; Bruce, A.T.; Ikeda, H.; Old, L.J.; Schreiber, R.D. Cancer immunoediting: From immunosurveillance to tumor escape. Nat. Immunol. 2002, 3, 991-998. [CrossRef]

88. Dunn, G.P.; Old, L.J.; Schreiber, R.D. The three Es of cancer immunoediting. Annu. Rev. Immunol. 2004, 22, 329-360. [CrossRef]

89. Opejin, A.; Surnov, A.; Misulovin, Z.; Pherson, M.; Gross, C.; Iberg, C.A.; Fallahee, I.; Bourque, J.; Dorsett, D.; Hawiger, D. A Two-Step Process of Effector Programming Governs CD4(+) T Cell Fate Determination Induced by Antigenic Activation in the Steady State. Cell Rep. 2020, 33, 108424. [CrossRef]

90. Surnov, A.; Hawiger, D. The formation of pre-effectors in the steady state opens a new perspective for cancer immunosurveillance. Oncotarget 2021, 12, 1318-1320. [CrossRef]

91. Kalekar, L.A.; Mueller, D.L. Relationship between CD4 Regulatory T Cells and Anergy in vivo. J. Immunol. 2017, 198, 2527-2533. [CrossRef] [PubMed]

92. Jones, A.; Hawiger, D. Peripherally Induced Regulatory T Cells: Recruited Protectors of the Central Nervous System against Autoimmune Neuroinflammation. Front. Immunol. 2017, 8, 532. [CrossRef] [PubMed]

93. Munn, D.H.; Sharma, M.D.; Lee, J.R.; Jhaver, K.G.; Johnson, T.S.; Keskin, D.B.; Marshall, B.; Chandler, P.; Antonia, S.J.; Burgess, R.; et al. Potential regulatory function of human dendritic cells expressing indoleamine 2,3-dioxygenase. Science 2002, 297, 1867-1870. [CrossRef] [PubMed]

94. Mucida, D.; Park, Y.; Kim, G.; Turovskaya, O.; Scott, I.; Kronenberg, M.; Cheroutre, H. Reciprocal TH17 and regulatory T cell differentiation mediated by retinoic acid. Science 2007, 317, 256-260. [CrossRef] 
95. Coombes, J.L.; Siddiqui, K.R.; Arancibia-Carcamo, C.V.; Hall, J.; Sun, C.M.; Belkaid, Y.; Powrie, F. A functionally specialized population of mucosal CD103+ DCs induces Foxp3+ regulatory T cells via a TGF-beta and retinoic acid-dependent mechanism. J. Exp. Med. 2007, 204, 1757-1764. [CrossRef] [PubMed]

96. Sun, C.M.; Hall, J.A.; Blank, R.B.; Bouladoux, N.; Oukka, M.; Mora, J.R.; Belkaid, Y. Small intestine lamina propria dendritic cells promote de novo generation of Foxp3 T reg cells via retinoic acid. J. Exp. Med. 2007, 204, 1775-1785. [CrossRef] [PubMed]

97. Manicassamy, S.; Ravindran, R.; Deng, J.; Oluoch, H.; Denning, T.L.; Kasturi, S.P.; Rosenthal, K.M.; Evavold, B.D.; Pulendran, B. Toll-like receptor 2-dependent induction of vitamin A-metabolizing enzymes in dendritic cells promotes $\mathrm{T}$ regulatory responses and inhibits autoimmunity. Nat. Med. 2009, 15, 401-409. [CrossRef]

98. Li, M.O.; Flavell, R.A. Contextual regulation of inflammation: A duet by transforming growth factor-beta and interleukin-10. Immunity 2008, 28, 468-476. [CrossRef]

99. Mascanfroni, I.D.; Yeste, A.; Vieira, S.M.; Burns, E.J.; Patel, B.; Sloma, I.; Wu, Y.; Mayo, L.; Ben-Hamo, R.; Efroni, S.; et al. IL-27 acts on DCs to suppress the T cell response and autoimmunity by inducing expression of the immunoregulatory molecule CD39. Nat. Immunol. 2013, 14, 1054-1063. [CrossRef]

100. Bourque, J.; Hawiger, D. Immunomodulatory Bonds of the Partnership between Dendritic Cells and T Cells. Crit. Rev. Immunol. 2018, 38, 379-401. [CrossRef]

101. Bourque, J.; Hawiger, D. The BTLA-HVEM-CD5 Immunoregulatory Axis-An Instructive Mechanism Governing pTreg Cell Differentiation. Front. Immunol. 2019, 10, 1163. [CrossRef] [PubMed]

102. Yin, X.; Chen, S.; Eisenbarth, S.C. Dendritic Cell Regulation of T Helper Cells. Annu. Rev. Immunol. 2021, 39, 759-790. [CrossRef] [PubMed]

103. Henderson, J.G.; Opejin, A.; Jones, A.; Gross, C.; Hawiger, D. CD5 Instructs Extrathymic Regulatory T Cell Development in Response to Self and Tolerizing Antigens. Immunity 2015, 42, 471-483. [CrossRef] [PubMed]

104. Idoyaga, J.; Cheong, C.; Suda, K.; Suda, N.; Kim, J.Y.; Lee, H.; Park, C.G.; Steinman, R.M. Cutting edge: Langerin/CD207 receptor on dendritic cells mediates efficient antigen presentation on MHC I and II products in vivo. J. Immunol. 2008, 180, 3647-3650. [CrossRef]

105. Igyártó, B.Z.; Haley, K.; Ortner, D.; Bobr, A.; Gerami-Nejad, M.; Edelson, B.T.; Zurawski, S.M.; Malissen, B.; Zurawski, G.; Berman, J.; et al. Skin-Resident Murine Dendritic Cell Subsets Promote Distinct and Opposing Antigen-Specific T Helper Cell Responses. Immunity 2011, 35, 260-272. [CrossRef] [PubMed]

106. Valladeau, J.; Ravel, O.; Dezutter-Dambuyant, C.; Moore, K.; Kleijmeer, M.; Liu, Y.; Duvert-Frances, V.; Vincent, C.; Schmitt, D.; Davoust, J.; et al. Langerin, a novel C-type lectin specific to Langerhans cells, is an endocytic receptor that induces the formation of Birbeck granules. Immunity 2000, 12, 71-81. [CrossRef]

107. Kissenpfennig, A.; Henri, S.; Dubois, B.; Laplace-Builhe, C.; Perrin, P.; Romani, N.; Tripp, C.H.; Douillard, P.; Leserman, L.; Kaiserlian, D.; et al. Dynamics and function of Langerhans cells in vivo: Dermal dendritic cells colonize lymph node areas distinct from slower migrating Langerhans cells. Immunity 2005, 22, 643-654. [CrossRef]

108. Takahara, K.; Omatsu, Y.; Yashima, Y.; Maeda, Y.; Tanaka, S.; Iyoda, T.; Clausen, B.E.; Matsubara, K.; Letterio, J.; Steinman, R.M.; et al. Identification and expression of mouse Langerin (CD207) in dendritic cells. Int. Immunol. 2002, 14, 433-444. [CrossRef]

109. Cheong, C.; Idoyaga, J.; Do, Y.; Pack, M.; Park, S.H.; Lee, H.; Kang, Y.S.; Choi, J.H.; Kim, J.Y.; Bonito, A.; et al. Production of monoclonal antibodies that recognize the extracellular domain of mouse langerin/CD207. J. Immunol. Methods 2007, 324, 48-62. [CrossRef]

110. Douillard, P.; Stoitzner, P.; Tripp, C.H.; Clair-Moninot, V.; Ait-Yahia, S.; McLellan, A.D.; Eggert, A.; Romani, N.; Saeland, S. Mouse lymphoid tissue contains distinct subsets of langerin/CD207 dendritic cells, only one of which represents epidermal-derived Langerhans cells. J. Investig. Dermatol. 2005, 125, 983-994. [CrossRef]

111. Galustian, C.; Park, C.G.; Chai, W.; Kiso, M.; Bruening, S.A.; Kang, Y.S.; Steinman, R.M.; Feizi, T. High and low affinity carbohydrate ligands revealed for murine SIGN-R1 by carbohydrate array and cell binding approaches, and differing specificities for SIGN-R3 and langerin. Int. Immunol. 2004, 16, 853-866. [CrossRef] [PubMed]

112. Stambach, N.S.; Taylor, M.E. Characterization of carbohydrate recognition by langerin, a C-type lectin of Langerhans cells. Glycobiology 2003, 13, 401-410. [CrossRef] [PubMed]

113. de Witte, L.; Nabatov, A.; Pion, M.; Fluitsma, D.; de Jong, M.A.; de Gruijl, T.; Piguet, V.; van Kooyk, Y.; Geijtenbeek, T.B. Langerin is a natural barrier to HIV-1 transmission by Langerhans cells. Nat. Med. 2007, 13, 367-371. [CrossRef]

114. Takahara, K.; Yashima, Y.; Omatsu, Y.; Yoshida, H.; Kimura, Y.; Kang, Y.S.; Steinman, R.M.; Park, C.G.; Inaba, K. Functional comparison of the mouse DC-SIGN, SIGNR1, SIGNR3 and Langerin, C-type lectins. Int. Immunol. 2004, 16, 819-829. [CrossRef] [PubMed]

115. Flacher, V.; Douillard, P.; Ait-Yahia, S.; Stoitzner, P.; Clair-Moninot, V.; Romani, N.; Saeland, S. Expression of langerin/CD207 reveals dendritic cell heterogeneity between inbred mouse strains. Immunology 2008, 123, 339-347. [CrossRef]

116. Bigley, V.; McGovern, N.; Milne, P.; Dickinson, R.; Pagan, S.; Cookson, S.; Haniffa, M.; Collin, M. Langerin-expressing dendritic cells in human tissues are related to CD1c+ dendritic cells and distinct from Langerhans cells and CD141high XCR1+ dendritic cells. J. Leukoc. Biol. 2015, 97, 627-634. [CrossRef]

117. Haniffa, M.; Shin, A.; Bigley, V.; McGovern, N.; Teo, P.; See, P.; Wasan, P.S.; Wang, X.N.; Malinarich, F.; Malleret, B.; et al. Human tissues contain CD141hi cross-presenting dendritic cells with functional homology to mouse CD103+ nonlymphoid dendritic cells. Immunity 2012, 37, 60-73. [CrossRef] 
118. Bertram, K.M.; Botting, R.A.; Baharlou, H.; Rhodes, J.W.; Rana, H.; Graham, J.D.; Patrick, E.; Fletcher, J.; Plasto, T.M.; Truong, N.R.; et al. Identification of HIV transmitting CD11c+ human epidermal dendritic cells. Nat. Commun. 2019, 10, 2759. [CrossRef]

119. Hemmi, H.; Idoyaga, J.; Suda, K.; Suda, N.; Kennedy, K.; Noda, M.; Aderem, A.; Steinman, R.M. A new triggering receptor expressed on myeloid cells (Trem) family member, Trem-like 4, binds to dead cells and is a DNAX activation protein 12-linked marker for subsets of mouse macrophages and dendritic cells. J. Immunol. 2009, 182, 1278-1286. [CrossRef]

120. Caminschi, I.; Proietto, A.I.; Ahmet, F.; Kitsoulis, S.; Shin Teh, J.; Lo, J.C.; Rizzitelli, A.; Wu, L.; Vremec, D.; van Dommelen, S.L.; et al. The dendritic cell subtype-restricted C-type lectin Clec9A is a target for vaccine enhancement. Blood 2008, 112, 3264-3273. [CrossRef]

121. Huysamen, C.; Willment, J.A.; Dennehy, K.M.; Brown, G.D. CLEC9A is a novel activation C-type lectin-like receptor expressed on BDCA3+ dendritic cells and a subset of monocytes. J. Biol. Chem. 2008, 283, 16693-16701. [CrossRef] [PubMed]

122. Sancho, D.; Mourao-Sa, D.; Joffre, O.P.; Schulz, O.; Rogers, N.C.; Pennington, D.J.; Carlyle, J.R.; Reis e Sousa, C. Tumor therapy in mice via antigen targeting to a novel, DC-restricted C-type lectin. J. Clin. Investig. 2008, 118, 2098-2110. [CrossRef] [PubMed]

123. Sancho, D.; Joffre, O.P.; Keller, A.M.; Rogers, N.C.; Martinez, D.; Hernanz-Falcon, P.; Rosewell, I.; Reis e Sousa, C. Identification of a dendritic cell receptor that couples sensing of necrosis to immunity. Nature 2009, 458, 899-903. [CrossRef] [PubMed]

124. Tacken, P.J.; de Vries, I.J.; Torensma, R.; Figdor, C.G. Dendritic-cell immunotherapy: From ex vivo loading to in vivo targeting Nat. Rev. Immunol. 2007, 7, 790-802. [CrossRef]

125. Jongbloed, S.L.; Kassianos, A.J.; McDonald, K.J.; Clark, G.J.; Ju, X.; Angel, C.E.; Chen, C.J.; Dunbar, P.R.; Wadley, R.B.; Jeet, V.; et al. Human CD141+ (BDCA-3)+ dendritic cells (DCs) represent a unique myeloid DC subset that cross-presents necrotic cell antigens. J. Exp. Med. 2010, 207, 1247-1260. [CrossRef]

126. Poulin, L.F.; Salio, M.; Griessinger, E.; Anjos-Afonso, F.; Craciun, L.; Chen, J.L.; Keller, A.M.; Joffre, O.; Zelenay, S.; Nye, E.; et al. Characterization of human DNGR-1+ BDCA3+ leukocytes as putative equivalents of mouse CD8alpha+ dendritic cells. J. Exp. Med. 2010, 207, 1261-1271. [CrossRef]

127. Schreibelt, G.; Klinkenberg, L.J.; Cruz, L.J.; Tacken, P.J.; Tel, J.; Kreutz, M.; Adema, G.J.; Brown, G.D.; Figdor, C.G.; de Vries, I.J. The C-type lectin receptor CLEC9A mediates antigen uptake and (cross-)presentation by human blood BDCA3+ myeloid dendritic cells. Blood 2012, 119, 2284-2292. [CrossRef]

128. Masterman, K.-A.; Haigh, O.L.; Tullett, K.M.; Leal-Rojas, I.M.; Walpole, C.; Pearson, F.E.; Cebon, J.; Schmidt, C.; Brien, L.; Rosendahl, N.; et al. Human CLEC9A antibodies deliver NY-ESO-1 antigen to CD141+ dendritic cells to activate naïve and memory NY-ESO-1-specific CD8+ T cells. J. Immunother. Cancer 2020, 8, e000691. [CrossRef]

129. Vremec, D.; Zorbas, M.; Scollay, R.; Saunders, D.J.; Ardavin, C.F.; Wu, L.; Shortman, K. The surface phenotype of dendritic cells purified from mouse thymus and spleen: Investigation of the CD8 expression by a subpopulation of dendritic cells. J. Exp. Med. 1992, 176, 47-58. [CrossRef]

130. Witmer, M.D.; Steinman, R.M. The anatomy of peripheral lymphoid organs with emphasis on accessory cells: Light-microscopic immunocytochemical studies of mouse spleen, lymph node, and Peyer's patch. Am. J. Anat. 1984, 170, 465-481. [CrossRef]

131. Klechevsky, E.; Banchereau, J. Human dendritic cells subsets as targets and vectors for therapy. Ann. N. Y. Acad. Sci. 2013, 1284, 24-30. [CrossRef]

132. Nagae, M.; Ikeda, A.; Hanashima, S.; Kojima, T.; Matsumoto, N.; Yamamoto, K.; Yamaguchi, Y. Crystal structure of human dendritic cell inhibitory receptor C-type lectin domain reveals the binding mode with N-glycan. FEBS Lett. 2016, $590,1552$. [CrossRef]

133. Meyer-Wentrup, F.; Cambi, A.; Joosten, B.; Looman, M.W.; de Vries, I.J.; Figdor, C.G.; Adema, G.J. DCIR is endocytosed into human dendritic cells and inhibits TLR8-mediated cytokine production. J. Leukoc. Biol. 2009, 85, 518-525. [CrossRef]

134. Uto, T.; Fukaya, T.; Takagi, H.; Arimura, K.; Nakamura, T.; Kojima, N.; Malissen, B.; Sato, K. Clec4A4 is a regulatory receptor for dendritic cells that impairs inflammation and T-cell immunity. Nat. Commun. 2016, 7, 11273. [CrossRef]

135. Asselin-Paturel, C.; Brizard, G.; Pin, J.J.; Briere, F.; Trinchieri, G. Mouse strain differences in plasmacytoid dendritic cell frequency and function revealed by a novel monoclonal antibody. J. Immunol. 2003, 171, 6466-6477. [CrossRef]

136. Blasius, A.; Vermi, W.; Krug, A.; Facchetti, F.; Cella, M.; Colonna, M. A cell-surface molecule selectively expressed on murine natural interferon-producing cells that blocks secretion of interferon-alpha. Blood 2004, 103, 4201-4206. [CrossRef]

137. Cao, W.; Bover, L.; Cho, M.; Wen, X.; Hanabuchi, S.; Bao, M.; Rosen, D.B.; Wang, Y.H.; Shaw, J.L.; Du, Q.; et al. Regulation of TLR7/9 responses in plasmacytoid dendritic cells by BST2 and ILT7 receptor interaction. J. Exp. Med. 2009, 206, 1603-1614. [CrossRef]

138. Collison, J. Autoimmunity: Siglec-H protects mice from lupus-like disease. Nat. Rev. Rheumatol. 2016, 12, 498. [CrossRef]

139. Sapoznikov, A.; Fischer, J.A.; Zaft, T.; Krauthgamer, R.; Dzionek, A.; Jung, S. Organ-dependent in vivo priming of naive CD4+, but not CD8+, T cells by plasmacytoid dendritic cells. J. Exp. Med. 2007, 204, 1923-1933. [CrossRef]

140. Macri, C.; Dumont, C.; Johnston, A.P.; Mintern, J.D. Targeting dendritic cells: A promising strategy to improve vaccine effectiveness. Clin. Transl. Immunol. 2016, 5, e66. [CrossRef]

141. Cohn, L.; Chatterjee, B.; Esselborn, F.; Smed-Sorensen, A.; Nakamura, N.; Chalouni, C.; Lee, B.C.; Vandlen, R.; Keler, T.; Lauer, P.; et al. Antigen delivery to early endosomes eliminates the superiority of human blood BDCA3+ dendritic cells at cross presentation. J. Exp. Med. 2013, 210, 1049-1063. [CrossRef] [PubMed] 
142. Gurer, C.; Strowig, T.; Brilot, F.; Pack, M.; Trumpfheller, C.; Arrey, F.; Park, C.G.; Steinman, R.M.; Munz, C. Targeting the nuclear antigen 1 of Epstein-Barr virus to the human endocytic receptor DEC-205 stimulates protective T-cell responses. Blood 2008, 112, 1231-1239. [CrossRef] [PubMed]

143. Trumpfheller, C.; Longhi, M.P.; Caskey, M.; Idoyaga, J.; Bozzacco, L.; Keler, T.; Schlesinger, S.J.; Steinman, R.M. Dendritic cell-targeted protein vaccines: A novel approach to induce T-cell immunity. J. Intern. Med. 2012, 271, 183-192. [CrossRef] [PubMed]

144. Park, C.G. Vaccine strategies utilizing C-type lectin receptors on dendritic cells in vivo. Clin. Exp. Vaccine Res. 2014, 3, 149-154. [CrossRef]

145. Cheong, C.; Choi, J.H.; Vitale, L.; He, L.Z.; Trumpfheller, C.; Bozzacco, L.; Do, Y.; Nchinda, G.; Park, S.H.; Dandamudi, D.B.; et al. Improved cellular and humoral immune responses in vivo following targeting of HIV Gag to dendritic cells within human anti-human DEC205 monoclonal antibody. Blood 2010, 116, 3828-3838. [CrossRef]

146. Sehgal, K.; Dhodapkar, K.M.; Dhodapkar, M.V. Targeting human dendritic cells in situ to improve vaccines. Immunol. Lett. 2014, 162, 59-67. [CrossRef]

147. Dhodapkar, M.V.; Sznol, M.; Zhao, B.; Wang, D.; Carvajal, R.D.; Keohan, M.L.; Chuang, E.; Sanborn, R.E.; Lutzky, J.; Powderly, J.; et al. Induction of antigen-specific immunity with a vaccine targeting NY-ESO-1 to the dendritic cell receptor DEC-205. Sci. Transl. Med. 2014, 6, 232ra251. [CrossRef]

148. Woodham, A.W.; Cheloha, R.W.; Ling, J.; Rashidian, M.; Kolifrath, S.C.; Mesyngier, M.; Duarte, J.N.; Bader, J.M.; Skeate, J.G.; Da Silva, D.M.; et al. Nanobody-Antigen Conjugates Elicit HPV-Specific Antitumor Immune Responses. Cancer Immunol. Res. 2018, 6, 870. [CrossRef]

149. Fang, T.; Van Elssen, C.H.M.J.; Duarte, J.N.; Guzman, J.S.; Chahal, J.S.; Ling, J.; Ploegh, H.L. Targeted antigen delivery by an anti-class II MHC VHH elicits focused $\alpha$ MUC1(Tn) immunity. Chem. Sci. 2017, 8, 5591-5597. [CrossRef]

150. Duarte, J.N.; Cragnolini, J.J.; Swee, L.K.; Bilate, A.M.; Bader, J.; Ingram, J.R.; Rashidfarrokhi, A.; Fang, T.; Schiepers, A.; Hanke, L.; et al. Generation of Immunity against Pathogens via Single-Domain Antibody-Antigen Constructs. J. Immunol. 2016, 197, 4838. [CrossRef]

151. Pishesha, N.; Harmand, T.; Smeding, L.Y.; Ma, W.; Ludwig, L.S.; Janssen, R.; Islam, A.; Xie, Y.J.; Fang, T.; McCaul, N.; et al. Induction of antigen-specific tolerance by nanobody-antigen adducts that target class-II major histocompatibility complexes. Nat. Biomed. Eng. 2021, 5, 1389-1401. [CrossRef] [PubMed]

152. Ring, S.; Maas, M.; Nettelbeck, D.M.; Enk, A.H.; Mahnke, K. Targeting of autoantigens to DEC205(+) dendritic cells in vivo suppresses experimental allergic encephalomyelitis in mice. J. Immunol. 2013, 191, 2938-2947. [CrossRef] [PubMed]

153. Ahmad, Z.A.; Yeap, S.K.; Ali, A.M.; Ho, W.Y.; Alitheen, N.B.; Hamid, M. scFv antibody: Principles and clinical application. Clin. Dev. Immunol. 2012, 2012, 980250. [CrossRef] [PubMed]

154. Miller, S.D.; Karpus, W.J. Experimental autoimmune encephalomyelitis in the mouse. Curr. Protoc. Immunol. 2007, 77, 15.1.1-15.1.18. [CrossRef]

155. Miller, S.D.; Karpus, W.J.; Davidson, T.S. Experimental autoimmune encephalomyelitis in the mouse. Curr. Protoc. Immunol. 2010, 88, 15.1.1-15.1.20. [CrossRef] [PubMed]

156. Getts, D.R.; Martin, A.J.; McCarthy, D.P.; Terry, R.L.; Hunter, Z.N.; Yap, W.T.; Getts, M.T.; Pleiss, M.; Luo, X.; King, N.J.; et al. Microparticles bearing encephalitogenic peptides induce T-cell tolerance and ameliorate experimental autoimmune encephalomyelitis. Nat. Biotechnol. 2012, 30, 1217-1224. [CrossRef]

157. Miller, S.D.; Turley, D.M.; Podojil, J.R. Antigen-specific tolerance strategies for the prevention and treatment of autoimmune disease. Nat. Rev. Immunol. 2007, 7, 665-677. [CrossRef] 